\title{
Time of Appearance of Immunoglobulin-Containing Cells in the Mucosa of the Neonatal Intestine
}

\author{
M. PERKKIÖ ${ }^{(23)}$ AND E. SAVILAHTI
}

Children's Hospital, University of Helsinki, Helsinki, Finland

\begin{abstract}
Summary
In 46 intestinal specimens from infants $2 \mathrm{hr}$ to 6 months old, the numbers of immunoglobulin-containing cells were counted by the direct immunofluorescent or direct immunoperoxidase technique. A restudy was made of biopsy specimens taken for diagnostic purposes, 34 from the rectum and 3 from the transverse colon of 30 infants at the Children's Hospital, Helsinki in 1971-1977, and in addition, of autopsy material recently collected from the intestines of 9 infants. Up to the age of 12 days, no immunoglobulincontaining cells were seen. A small number (1 to 2) of IgMcontaining cells was seen in the lymph nodes of the 2 earlier specimens taken at the ages of 6 and 12 days. A rectal specimen from a 12-day-old infant showed $24 \mathrm{IgA}$ - and $60 \mathrm{IgM}$-containing cells $/ \mathrm{mm}^{2}$. In rectal specimens of infants less than 1 month old, the mean number of IgM-containing cells $\left(26 / \mathrm{mm}^{2}\right)$ was higher than that of IgA-containing cells $\left(14 / \mathrm{mm}^{2}\right)$, but older infants had a significantly higher mean number of IgA-containing cells $(P<$ 0.01 ). The mean number of IgM-containing cells was the same in children 1 to 3 months ( 53 cells $/ \mathrm{mm}^{2}$ ) and 3 to 6 months of age $\left(59\right.$ cells $\left./ \mathrm{mm}^{2}\right)$, whereas the mean number of IgA-containing cells increased with age up to 6 months (112 and 163 cells $/ \mathrm{mm}^{2}$ ). The youngest infant who had IgG-containing cells was 13 days old, although positive staining of intercellular spaces in the lamina propria and of the capillary endothelium by anti-IgG serum was observed in all specimens. The mean number of IgG-containing cells was low ( 5 cells $/ \mathrm{mm}^{2}$ ) in all age groups. Sparse IgE-containing cells (less than $12 / \mathrm{mm}^{2}$ ) were seen in 4 of the 46 specimens. In 5 patients, 2 or 3 consecutive specimens were available for the study; in these, the increase in the numbers of $\operatorname{IgA}$ - and IgMcontaining cells was similar to the mean increase in cell numbers for the series as a whole.
\end{abstract}

\section{Speculation}

There is a deficiency of immunoglobulin-containing cells in the gut of newborn infants up to the age of 12 days, and this is probably the reason for the high permeability of the neonatal intestine to foreign proteins.

The local humoral immune system of the intestine is well characterized in adults $(1,3,18)$, but little is known about the development of the system in man. Plasma cells appear in the intestine of neonates at the age of 3 wk (2), and secretion of $\operatorname{IgA}$ into the saliva starts at the same age $(8,16)$. In the jejunal and rectal mucosa of infants aged 3 months to 2 years, the numbers of immunoglobulin-containing cells averaged four-fifths of the numbers seen in children 2 to 16 years old (15). A recent report (7) suggests that there is very early secretion of immunoglobulins by the cells of the rectum in infants.

The relative deficiency of secretory $\operatorname{IgA}$ in the newborn is the factor chiefly responsible (19) for the high permeability of the intestine of the young infant to native foreign proteins (10). This, together with ingestion of foreign proteins, e.g., cow's milk, has been blamed for the genesis of food allergy (11).
We have studied the time of appearance of immunoglobulincontaining cells in the intestine of newborn infants.

\section{MATERIALS AND METHODS}

\section{PATIENTS}

Thirty-seven biopsy specimens, 34 from the rectum and 3 from the transverse colon of 30 infants 1 day to 6 months old collected in 1971-1977 at the Children's Hospital, Helsinki, were restudied. Patients who had symptoms or signs suggestive of intestinal infection or malabsorption syndrome were excluded from the study. Fresh intestinal autopsy material was collected from a further 9 infants who died of cardiac or respiratory failure; 4 of these were born at term. A piece of upper jejunum was removed 2 to $8 \mathrm{hr}$ postmortem; 3 samples were taken in 1972 and 6 in 1978. The earlier samples were processed for direct immunofluorescent study (15), and the 6 later ones were fixed in formalin and stained with peroxidase-conjugated antisera as described below. Measurements made in 11 patients ( 8 of the rectal biopsy group and 3 of the autopsy group) showed that serum immunoglobulins were normal. Informed consent was obtained from the parents of all the infants before doing the autopsy.

\section{METHODS}

Rectal biopsies had been taken 4 to $10 \mathrm{~cm}$ proximally of the anal sphincter from infants suspected to have Hirschsprung's disease; the 3 biopsies from the colon were taken during transversostomy. Specimens were fixed in $10 \%$ formalin in phosphatebuffered saline and embedded in paraffin. The paraffin blocks were stored uncovered at room temperature.

Horseradish:peroxidase-conjugated rabbit antisera to human IgA, IgM, and IgG, specific for $\alpha-, \mu$-, and $\gamma$-chains, respectively, were obtained from Dakopatts (Copenhagen, Denmark) and conjugated goat antiserum to human IgE from Miles Laboratories (Elkhart, IN). The monospecificity of the antisera was checked by immunoelectrophoresis and by a double diffusion micromethod (15). The staining specificity was studied by blocking experiments with unlabeled rabbit antisera to human $\operatorname{IgA}$, IgM, and $\operatorname{IgG}$ (Hyland Lab, Inc., Costa Mesa, CA), and unlabeled goat antiserum to human IgE (Miles Laboratories). Control sections were stained with diaminobenzidine (DAB) alone and with normal swine $\gamma$-globulin conjugated with horseradish peroxidase in our own laboratory (12).

Paraffin sections of $5 \mu \mathrm{m}$ were attached to slides by warming in an oven at $60^{\circ} \mathrm{C}$ for one-half $\mathrm{hr}$ and deparaffinized through a series of xylene alcohols. The endogenous peroxidase activity was blocked by incubating the sections for $30 \mathrm{~min}$ in $0.5 \%$ hydrogen peroxide in methanol (13). The sections were then rinsed in distilled water and washed 3 times for $10 \mathrm{~min}$ in phosphatebuffered saline ( $\mathrm{pH} 7.0)$ with constant stirring. To reduce the background staining, the sections were incubated for $30 \mathrm{~min}$ with normal rabbit serum diluted 1:2 or with normal goat serum for IgE staining. The sections were then blotted and covered with one drop of appropriately diluted conjugated specific antiserum $(\operatorname{IgA}$, 
IgM, and $\operatorname{IgG}, 1: 5$, or $\operatorname{IgE}, 1: 16)$ for $1 \mathrm{hr}$ at room temperature. After thorough washing, the sections were incubated for $8 \mathrm{~min}$ with fresh DAB solution prepared immediately before use by dissolving $6 \mathrm{mg}$ of DAB (Sigma Chemical Co., St. Louis, MO) in $10 \mathrm{ml}$ Tris buffer $(0.05 \mathrm{M}$ in saline, $\mathrm{pH} 7.6)$, and adding $0.01 \%$ hydrogen peroxide (5). The sections were then washed, dehydrated, and mounted in Permount; no counterstaining was used. The stained sections were examined under the ordinary light microscope. The positively stained brown cells were counted directly on slides at $\times 1000$ from an area of at least $0.2 \mathrm{~mm}^{2}$ between the epithelium and the muscularis mucosae. The area occupied by Lieberkühn's crypt was not excluded (15).

\section{RESULTS}

No immunoglobulin-containing cells were seen in the lamina propria of 1 rectal, 1 colonic, and 7 jejunal specimens from infants less than 12 days old (Figs. I and 2). Occasional ( 1 to 2) IgMcontaining cells were seen in the lymph nodes of the 2 jejunal specimens taken at the ages of 6 and 12 days. A few $\operatorname{IgA-}$ and IgM-containing cells were observed in the lamina propria of the

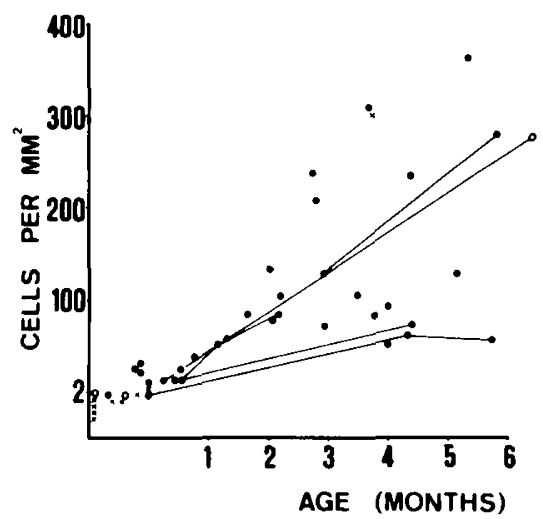

Fig. 1. IgA-containing cells in the lamina propria of rectal $(\bullet)$, colonic $(O)$, and jejunal $(x)$ biopsy specimens. The counts of the same infant are connected with a line.

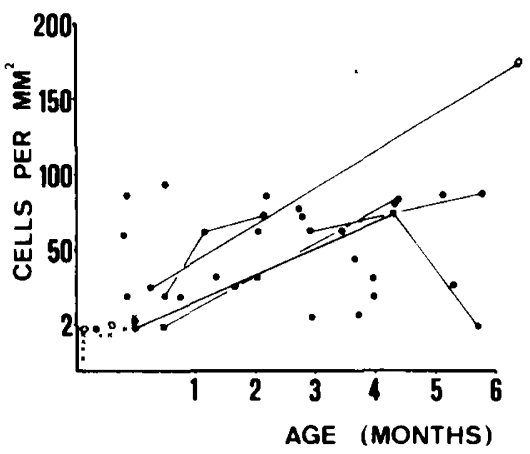

Fig. 2. IgM-containing cells in the lamina propria of rectal $(\Theta)$, colonic $(O)$, and jejunal $(x)$ biopsy specimens. Lines as in Figure 1. rectal specimen of the 12-day-old child. In specimens of infants more than 12 days old, both IgA- and IgM-containing cells were absent only from 1 specimen taken at the age of 15 days. In addition, IgM-containing cells were not seen in 2 specimens taken at the ages of 22 days and 5 months, 22 days. In 7 of 21 specimens from infants less than 1 month old, IgM-containing cells were more numerous than IgA-containing cells; in 3 specimens, IgAcontaining cells predominated. In older infants, IgA-containing cells predominated in 22 specimens, and IgM-containing cells dominated in 3 specimens.

In rectal specimens of infants less than 1 month old, the number of IgM-containing cells was higher than that of IgA-containing cells (Table 1). In infants 1 to 3 and 3 to 6 months of age, the mean number of IgA-containing cells was significantly higher than that of IgM-containing cells (Table 1). The mean number of IgA-containing cells increased, but the mean number of IgMcontaining cells was similar in infants aged 1 to 3 months and those aged 3 to 6 months.

Positive staining of intercellular spaces in the lamina propria and of the capillary endothelium by anti-IgG serum was observed in all specimens including those taken from newborn infants. However, the youngest infant who had IgG-containing cells in the rectal mucosa was 13 days old. The mean number of IgG-containing cells was low in all age groups (Table 1). Sparse (6 to $\left.12 / \mathrm{mm}^{2}\right)$ IgE-containing cells were present in 4 of the 46 specimens.

In the patients from whom more than 1 biopsy specimen was studied, the individual increase in the numbers of IgA- and IgMcontaining cells was much the same as the mean increase in cell numbers for the series as a whole (Figs. 1 and 2).

\section{DISCUSSION}

Up to the age of 12 days, both jejunal and rectal specimens lacked all immunoglobulin-containing cells. IgM- and IgA-containing cells appeared in the intestinal mucosa at the same age. In specimens from infants less than 1 month old, the cells that took up stain were mainly IgM-containing but in older infants these were significantly outnumbered by IgA-containing cells. The mean number of IgM-containing cells remained the same in children aged 1 to 6 months, but the mean number of IgAcontaining cells increased with age up to 6 months. Extracellular staining with anti-IgG serum was observed immediately after birth, and IgG-containing cells were seen from the age of 2 wk, although their number was low. IgE-containing cells were seen in only 4 specimens. The results tended to be similar in the rectal and jejunal mucosae.

Most of the material had been fixed in formalin and embedded in paraffin. Paraffin sections gave better preparations with the fresh jejunal autopsy specimens than with the preserved rectal biopsies in which more extracellular granulous staining was observed. Some of the small numbers of immunoglobulin-containing cells seen may have been artifacts due to denaturation and breakdown of proteins during routine processing and to the long preservation without any covering after primary sectioning. The positive staining of intercellular spaces with anti-IgG serum indicated that immunoreactive IgG was present in every specimen.

Table 1. Immunoglobulin-containing cells in the rectal or colonic mucosa (cells $/ \mathrm{mm}^{2}$ )

\begin{tabular}{|c|c|c|c|c|c|}
\hline \multicolumn{2}{|c|}{ Patients } & & & \multirow[b]{2}{*}{ IgM-containing cells } & \multirow[b]{2}{*}{ IgG-containing cell } \\
\hline Age & No. & \multicolumn{2}{|c|}{ IgA-containing cells } & & \\
\hline $0-1$ month & 13 & $\begin{array}{c}14 \pm 12^{1} \\
P<0.001^{2}\end{array}$ & NS & $\begin{array}{r}26 \pm 33 \\
P<0.05\end{array}$ & $5 \pm 7$ \\
\hline $1-3$ months & 11 & $\begin{array}{l}112 \pm 61 \\
\text { NS }\end{array}$ & $P<0.01$ & $\begin{array}{l}53 \pm 26 \\
\text { NS }\end{array}$ & $4 \pm 5$ \\
\hline $\begin{array}{l}3-6 \text { months } \\
3 \text { months }-2 \text { yr (15) }\end{array}$ & $\begin{array}{r}13 \\
8\end{array}$ & $\begin{array}{l}163 \pm 112 \\
408 \pm 125\end{array}$ & $P<0.005$ & $\begin{aligned} 59 & \pm 46 \\
137 & \pm 125\end{aligned}$ & $\begin{aligned} 6 & \pm 7 \\
54 & \pm 62\end{aligned}$ \\
\hline
\end{tabular}

${ }^{\prime}$ Mean \pm S.D.

${ }^{2}$ Student's $t$ test 
The appearance of the immunoglobulin-containing cells at the age of 12 days in this study is in keeping with the studies on secretory immunoglobulins in saliva. Selner et al. (16) reported that secretory $\operatorname{IgA}$ was present in the saliva of $90 \%$ of newborn infants by the age of 28 days. Haworth and Dilling (8) observed IgA in the saliva in 1 of 25 full-term neonates in the first wk of life, in one-half of these in the second wk, and in about $80 \%$ by the end of the third wk. In neonates of low birth weight, IgA appeared about a wk later.

No previous studies have investigated the time at which immuglobulin-containing cells appear in the intestinal mucosa of neonates. In his morphological study, Bridges et al. (2) found mature plasma cells in only 1 of 15 specimens of ileum and appendix from infants less than 1 month old, the number of plasma cells increasing up to the age of 3 years. Recently, Halpin et al. (7) showed that rectal biopsy specimens of infants whose mean age was 3 days did contain and secrete immunoglobulins when cultured for $18 \mathrm{hr}$. The mean number of $\operatorname{IgA}$-containing cells in children aged 3 months to $2 \mathrm{yr}$ is four-fifths of that seen in children 2 to 16 years of age. The number of IgM-containing cells does not increase after the age of 3 months in the rectal or jejunal mucosa (15). In children as in adults, there is a correlation between the numbers of IgA-containing cells in the rectal and jejunal mucosae $(4,15)$. In the present study, too, the numbers of immunoglobulin-containing cells in the jejunal and rectal specimens were alike. Combining these data, we conclude that the rise in the number of IgM-containing cells is rapid and complete by the age of 3 months. The rise in the number of $\operatorname{IgA}$-containing cells is much slower: although large numbers of these cells are seen at the age of 1 month, there is a further increase up to 6 months and even after the age of 2 yr (15).

Foreign proteins tend to be absorbed in antigenic form, especially in young infants $(6,9,10,14)$. Absorption of macromolecules was significantly less strong in immunized rats than in controls, suggesting that the absorption of undigested macromolecules is inhibited by local excretion of antibodies (21). In man, this immune barrier in the intestine is provided by secretory immunoglobulins, primarily by secretory $\operatorname{IgA}$ but also by $\operatorname{IgM}(1,3,18)$.

Our results show that the human intestine lacks this system during the first 10 days of life; this finding is in agreement with earlier studies on the salivary excretion of immunoglobulins (8, 16). This deficiency in secretory immunoglobulins is probably the most important factor in the high permeability of the neonatal intestine, which allows formation of antibodies to foreign proteins (20) and may play a part in the pathogenesis of food allergy (11, 17).

\section{REFERENCES AND NOTES}

1. Brandtzaeg, P., and Baklien, K.: Intestinal secretion of IgA and IgM: a hypothetical model. In: Immunology of the Gut, Ciba Foundation Symposium 46 (new series), p. 77 (Amsterdam, Elsevier, 1977).
2. Bridges, R. A., Condie, R. M., Zak, S. J., and Good, R. A.: The morphologic basis of antibody formation development during the neonatal period. J. Lab. Clin. Med., 53: 331 (1959).

3. Brown, W. R.: Relationships between immunoglobulins and the intestinal epithelium. Gastroenterology, 75: 129 (1978).

4. Crabbé, P. A., and Heremans, J. F.: The distribution of immunoglobulin-containing cells along the human gastrointestinal tract. Gastroenterology, 51: 305 (1966).

5. Graham, R. C.. and Karnovsky, M. J.: The early stages of absorption of injected horseradish peroxidase and the proximal tubules of mouse kidney: ultrastructural cytochemistry by a new technique. J. Histochem. Cytochem.. 14: 291 (1966).

6. Gruskay, F. L., and Cooke, R. E.: The gastrointestinal absorption of unaltered protein in normal infants and in infants recovering from diarrhea. Pediatrics. 16: 763 (1955).

7. Halpin, T. C., Jr., Gregoire, R. P., and Izant, R. J.: Abnormal rectal immunoglobulin pattern in Hirschsprung's disease. Lancet, 2: 606 (1978).

8. Haworth, J. C., and Dilling. L.: Concentration of $\gamma$-A-globulin in serum, saliva, and nasopharyngeal secretions of infants and children. J. Lab. Clin. Med., 67: 922 (1966)

9. Leissring, J. C., Anderson, J. W., and Smith. D. W.: Uptake of antibodies by the intestine of the newborn infant. Am. J. Dis. Child., 103: 160 (1962).

10. Lippard, V. W.. Schloss, O. M., and Johnson, P. A.: Immune reactions induced in infants by intestinal absorption of incompletely digested cow's milk protein. Am. J. Dis. Child., 51:562 (1936).

11. Matthew, D. J., Taylor, B., Norman, A. P., Turner, M. W., and Soothill, J. F.: Prevention of eczema. Lancet, 1: 321 (1977).

12. Nakane, P. K., and Kawaoi, A.: Peroxidase-labeled antibody. A new method of conjugation. J. Histochem. Cytochem., 22: 1084 (1974).

13. Pinkus, G. S., and Said, J. W.: Specific identification of intracellular immunoglobulin in paraffin sections of multiple myeloma and macroglobulinemia using an immunoperoxidase technique. Am. J. Pathol., 87: 47 (1977).

14. Rothberg, R. M.: Immunoglobulin and specific antibody synthesis during the first weeks of life of premature infants. J. Pediatr., 75: 391 (1969).

15. Savilahti, E.: Immunoglobulin-containing cells in the intestinal mucosa and immunoglobulins in the intestinal juice in children. Clin. Exp. Immunol., 11: 415 (1972).

16. Selner, J. C., Merril, D. A., and Claman, H. N.: Salivary immunoglobulin and albumin. Development during the newborn period. J. Pediatr., 72: 685 (1968).

17. Taylor, B., Norman, A. P., Orgel, H. A.. Stokes, C. R., Turner, M. W., and Soothill, J. F.: Transient IgA deficiency and pathogenesis of infantile atopy. Lancet. 2: 111 (1973).

18. Tomasi, T. H., Jr., Tan, E. M.. Solomon, A., and Prendergast, R. A.: Characteristics of an immune system common to certain external secretions. J. Exp. Med., 121: 101 (1965).

19. Walker, W. A.: Host defence mechanisms in the gastrointestinal tract. Pediatrics, 57: 901 (1976).

20. Walker, W. A., and Isselbacher. K. J.: Uptake and transport of macromolecules by the intestine: possible role in clinical disorders. Gastroenterology, 67: 531 (1974).

21. Walker, W. A., Wu, M.. Isselbacher, K. J., and Bloch, K. J.: Intestinal uptake of macromolecules. III. Studies on the mechanism by which immunization interferes with antigen uptake. J. Immunol., 115: 854 (1975).

22. This paper was presented in part at the 12th Annual Meeting of the European Society for Paediatric Gastroenterology and Nutrition, London, May, 1979.

23. Requests for reprints should be addressed to: Dr. Perkkiö, Children's Hospital, University of Helsinki, Stenbäckinkatu II, SF-00290 Helsinki 29. Finland.

24. This research was supported by grants from the Foundation for Paediatric Research, Finland, and the Signe and Ane Gyllenberg Foundation.

25. Received for publication July II, 1979

26. Accepted for publication September 26, 1979. 